\title{
黒川紀章設計のカプセルと茶室に関する考察
}

\author{
「糓中」の世界観
}

\section{CONSIDERATION OF CAPSULE AND TEA ROOM DESIGNED BY KISHO KUROKAWA}

Worldview of "Kochuu"

\author{
和田 菜穂子*1
}

\section{Nahoko WADA}

\begin{abstract}
This paper aims to clarify the architect's vision from the viewpoint of capsule and tea room designed by Kisho Kurokawa.
The conclusions are as follows:

1. The expression of spoken and written words was equal to the expression of architecture.

2. The fundamental philosophy was formed by the experience of young ages. He learned the Buddhism at junior school and his grandfather gave a great impact to him.

3. Japanese Tradition gave him the inspiration for his new creation.

4. The worldview of "Kochuu" which means to feel universe at minimum space, was unvarying concept for his life.
\end{abstract}

Keywords: Kisho Kurokawa, Capsule, Tea Room, Kochuu, Hanasuki 黒川紀章, カプセル, 茶室, 壼中, 花数寄

\section{1. はじめに}

黒川紀章（以下、黒川とする）が設計し 1972 年に竣工した「中 銀カプセルタワービル」(以下、中銀カプセルとする) は世界を代表 するメタボリズム建築である。その特徴は取り替え可能とされたカ プセルがランダムに積み重なった姿である。黒川はカプセル一つ一 つを生物の細胞（セル）とみなし、それを取り替えることによって メタボリズムの概念である新陳代謝がなされると意図していた。カ プセルのサイズは男性一人が暮らすために必要な設備を有したわず か 10 平米の狭小空間であった。また黒川はほぼ同時期に自身の別 荘「カプセル K」注1) を実験住宅として手がけている。家族や友人と ともに利用することを想定し、4つのカプセルを組み合わせている。 注目すべきはその 1 つを茶室としている点である。黒川にとって茶 道は趣味の一つであった。

メタボリズムの概念は現実離れした構想ゆえ実現したものは数少 ない。1970 年代後半にはメタボリズム運動は収束していく。しかし 黒川が生涯に渡り、手がけ続けたのが茶室であった。1979 年に初め ての本格的数寄屋建築「杏樹荘」と茶室「栗明庵」を、1984 年には 自宅マンションにおいて茶室「唯識庵」を設計している。黒川は自 著『花数寄』で「数寄屋建築（茶室）は、日本人にとってその文化 のルーツを探るのに、きわめて重要な意味を持っている。（中略）建 築家にとって数寄屋建築は、日本建築の原点であるといってよいだ ろう」と述べている。茶室はカプセル同様狭小空間であるが、その
内部には日本人の美意識が凝縮されている。

本稿ではメタボリズムの核となったカプセルと茶室との関連性を 言及し、ミニマムな空間に求めた黒川の建築美学を明らかにするこ とを目的とする。

\section{2. 既往研究}

黒川は作品集のほか著述書も含め 137 冊注2) の図書がある。英語 や中国語など多言語を含んでいるが、これほど自らを語る建築家は 珍しい。黒川は自らを「思想家」と名乗り、『新・共生の思想』 （徳間書店、1996 年）等で思想の根幹を著している。また講演会 等でも「共生の思想」について弁舌をふるった。しかし最晚年にな ると政界進出を試み、建築家としての立ち振る舞いとはかけ離れた 街頭演説が記憶に残る。語らない建築家がいる反面、語る建築家の 代表格であった。

また黒川は建築ジャーナリズムを味方につけ、良好な関係を築い ていた。例えば建築雑誌『新建築』の編集長を長年務めていた馬場 璋造を例にしてみよう。『新建築』は一流建築家の最新作が紙面を 飾るという一種のステータスを持つ建築専門誌であるが、黒川は言 わずもがなその常連の一人であった。馬場との関係は彼が編集長を 退いた後も続いた。黒川が中心になり梅原猛を代表にして 1980 年 に設立した「日本文化デザイン会議」で馬場は 1995 年に開催され た福岡会議で議長を務めている。2000 年に開催された「黒川紀章

\footnotetext{
*1 東京建築アクセスポイント 代表理事・博士(学術) Representative Director, Access Point: Architecture-Tokyo, Ph.D.
} 
回顧展」では実行委員に名を連祆ており、黒川との長年にわたる蜜 月関係が読み取れる。

かつて朝日新聞社の記者であった松葉一清は建築評論家の一人で ある。2000 年の「黒川紀章回顧展」の図録に「黒川紀章の 7 つの コトバ」という論文を寄せている。「黒川紀章は「コトバ」のひと だと思われている。立て板に水とはこういうことを指すのかと思え るほどさわやかな弁舌が、そう思い込ませているのである。実際メ タボリズムをはじめ、彼が惹句の名手であることは周知の事実であ る。しかし、黒川は建築偏愛者であり、その意味では断じて「コト バ」だけのひとではない。彼はあくまで建築家なのであり、彼のす ばらしい惹句は、建築家として発したものなのである。それなら ば、「コトバ」は彼の作品や思考を理解する上で、決してじやます るものではないし、なによりの手がかりとなるはずだ」。黒川がい かに饒舌な語り部であったかが如実に示されている。

そのほか、ケネス・フランプトン、ジェフリー・キプニス、飯島 洋一らが作品集『JA 18 黒川紀章』（新建築社、1995 年）の冒頭 に論考を寄せ、ロンドンの建築家・建築評論家のデニス・シャープ は『黒川紀章回顧展図録』（1999 年）に寄稿している。

建築史家に関しては少し遡るが『黒川紀章作品集』（1986 年、 新建築社）で村松貞次郎が「私の黒川紀章論」を、鈴木博之が「図 像の離陸」と題した評論を掲載している。村松の論でも「”つくっ たものは、考えたことの 10 分の 1 にも満たぬ。だから語らねばな らぬ “と彼はいう」と黒川を「語る建築家」として位置付けてい る。黒川の講演録の小冊子『近代建築のどこが悪いか』を絶賛し、 「宝石箱のようなアンソロジーであり、また彼の近代建築を超える 誓言集ともなっている」とも記している。

建築史家・評論家の五十嵐太郎は大阪万博に関心をもち、2004 年に黒川にインタヴューを行ない、雑誌『10 +1（テンプラスワ ン）』にその記録を掲載している注3)。このようにプロとして言葉 を紡ぐ存在の建築ジャーナリス卜、建築評論家、建築史家らを掌中 に収めていたという点において、策略家であったといえよう。

メタボリズム論に関しては 2000 年代になると再考の時期とな り、2011 年にレム・コールハースらが『Project Japan: Metabolism Talks』注4)を上梓し、同年に森美術館で「メタボリズムの未来都市 展」が開催され、その代表格である中銀カプセルはもちろんのこ と、実現していない「農村都市計画」等のプロポーザルも取り上げ られた。黒川のカプセル建築に関しては、日本建築学会大会（関 東）学術講演梗概集 2006 年 9 月に「黒川紀章のカプセル概念 都 市からの再考」と題して東京理科大学の大貫健太郎、川向正人が論 じている。2014 年には「黒川紀章のメタボリズム思想と中銀カプ セルタワービルの現状」と題して東京電機大学の菅井隆史、横手義 洋が日本建築学会大会 (近畿) 学術講演梗概集 2014 年 9 月にて発 表している。前者は黒川のカプセル建築について、スペースフレー ムとの組み合わせによって展開していたことに注目し、都市との関 連性を言及している。また「ホモ・モーベンス」という黒川の概念 と絡めてカプセルの理念を論じている。後者は一度もカプセルの交 換が行われず老朽化が著しい中銀カプセルの現状と問題点を論じて いる。

このように黒川紀章に関する研究論文はカプセルやメタボリズム に関連するものが散見されるが、茶室に注目してカプセルと結び付
けたものは本研究が唯一である。黒川に対する新しい着眼点を帯び た新規性のある研究と位置付けられる。

\section{3. 研究方法、研究内容}

黒川に関する既往論文は前述したようにメタボリズムやカプセル に関するものがほとんどで、茶室や数寄屋建築に関するものは本人 の論考を除き、研究論文は見当たらない。そこで本研究では「語る 建築家」と評された黒川が著した書籍や論考洋5)をもとに仮説を立て、 立証していくことにする。

本研究における筆者の仮説は以下である。朱来志向のカプセル空 間は日本の伝統的な茶室空間から影響を受けているのではないか」。 まず 1969 年に黒川が発表した「カプセル宣言」に注目してみたい。 次に 1973 年に自身の別荘内に設けられた「カプセル茶室」に着目 する。ミニマムなカプセル空間を茶室に見立てているが、その内部 は小堀遠州の伝統的な茶室の写しであった。その後、本格的な数寄 屋建築を手がけ、現代茶室の試みへと移行していく。

本研究では茶室を発表する際、掲載誌で述べられた黒川の言説を 中心に読み解き、時系列に沿って以下の 6 つの論点で進めていく。

1 黒川にとってのカプセルとは

2 カプセル建築の実例

3 見立てのカプセル茶室

4 数寄屋建築への関心

5 言葉やキーワードの重要性

6 現代茶室への移行

カプセルという工業製品による単位空間と、日本の伝統文化の象 徵である茶室という一見すると性質の異なるものを取り上げるが、 本研究の目的はミニマムな空間に黒川が求めた美学や哲学を明らか にすることにある。

\section{4. 黒川紀章にとってのカプセルとは :「カプセル宣言」より}

黒川は雑誌『SD 特集 : カプセルの概念の拡張』(1969 年 3 月号) で「Oh!サイボーグの掟」と題して、8 条からなる「カプセル宣言」 を打ち出している。その時点ではカプセル建築はディスコ「スペー ス・カプセル」以外なかったため（Table1）、紙面の中央に「箱型量 産アパートメント計画」洋6) の模型写真を配し、そのイメージを伝え ている。その条文の冒頭を以下に挙げる。

第1条：カプセルとはサイボーグ・アーキテクチュアである。

第2条：カプセルとはホモ・モーベンス一動民のためのすまいで ある。

第3 条: カプセルは多称性社会を指向する。

第4条：カプセルは個人を中心とする新しい家庭像の確立を目指 す。

第 5 条：カプセルはふるさととしてのメタポリスをもつ。

第 6 条:カプセルは情報社会におけるフィードバック装置であり、 場合によっては、情報を拒否する装置である。

第 7 条：カプセルはプレハブ建築一工業化建築の究極的な存在で ある。

第8条：カプセルは全体性を拒否し、大系的思想を拒否する。 黒川は目を惹くキーワードを掲げ、それを捕捉する形で言葉を繋げ ていく論法を取っている。「Oh!サイボーグの掟」と題し、第 1 条に 
「カプセルとはサイボーグ・アーキテクチュアである」と掲げてい る。しかし実際にカプセルを用いた建築が登場し始めると、「サイボ ーグ」という言葉は消え失せ、新陳代謝を意味する「メタボリズム」 という言葉がそれに取って代わる。SD 掲載直後に刊行された自著 『ホモ・モーベンス 都市と人間の未来』(中公新書、1969 年) の巻 末にも「カプセル宣言」の条文と補足する文章に頁が割かれている。

新しい概念を新しい言葉で紡いでいく黒川のスタイルはこの「カ プセル宣言」に表出しているが、本稿では条文全てを論述せず第 2 条に掲げられている「ホモ・モーベンス」に着目寸る。「ホモ・モー ベンス」という言葉は黒川が独創したものではなく、あとがきによ れば多田道太郎氏との合作だと述べている注7。黑川は「動民」を「ホ モ・モーベンス」と訳し、未来的な意味を付加した。カプセル宣言 の第 2 条では、土地に定着せず自由に動く人々を「ホモ・モーベン ス」と呼び、土地や大邸宅という不動産を、人々は次第に欲求しな いようになり、より自由に動ける機会と手段をもつことに、価値観 を見出すだろう」注8) と述べている。アメリカで普及しているトレー ラー・ハウスを参照し、カプセルを用いた新しい住まいのあり方を 説いている。特に週末など余暇を過ごすセカンド・ハウスは移動可 能なものを推奨している。

Table1 Capsule Architecture by Kisho Kurokawa

\begin{tabular}{|l|l|l|}
\hline 名称 & 用途 & 竣工年 \\
\hline スペース・カプセル & ディスコ & 1968 \\
\hline タカラ・ビューティリオン & 大阪万博パヴィリオン & 1970 \\
\hline 空中テーマ館 住宅カプセル & 大阪万博パヴィリオン & 1970 \\
\hline 中銀カプセルタワービル & 集合住宅 & 1972 \\
\hline カプセルK & 別荘 & 1973 \\
\hline 大阪ソニータワー & ショールーム & 1976 \\
\hline
\end{tabular}

\section{5. カプセル建築の実例}

\section{(1) 大阪万博のパヴィリオン (1970 年竣エ)}

カプセル建築が日の目を見るのは 1970 年の大阪万博である。黒 川は3つのパヴィリオンを手がけ、そのうち「タカラ・ビューティ リオン」、「空中テーマ館 住宅カプセル」の 2 つでカプセルを用い た。万博は期間限定の催事であるため、解体を前提としている。「新 陳代謝」を意味するメタボリズムは、万博を通じ「増殖・成長・分 裂・破壊」の仕組みを広く一般の人に広める契機となった。黒川は 万博前の組立作業をメタボリズムの始まりと捉えた。プレファブリ ケーションの仕組みを取り入れ、工場から出荷し現場で組み立てる 建設中の記録を残し、雑誌等で発表した。これはカプセル宣言第 7 条「プレファブ建築」の実例を示したことになる。

ところで黒川が「プレファブ建築」に可能性を見出したのは、万 博よりさらに 10 年も遡る。黒川は 1958 年にモスクワで行われた 「世界建築学生会議」に参加した後、ソ連のプレファブコンクリー 卜住宅の量産工場や建設現場を視察している。帰国後、持ち帰った 資料を元に、初めての著書『プレファブ住宅』(彰国社、1960 年) を出版した。その後、カプセル建築の原型ともいえる「箱型量産ア パート計画」を 1962 年に提案。つまり「プレファブ建築」に精通 していた黒川にとって組立・解体が可能な仕組みを、カプセルを用 いて大阪万博で披露することは願ってもない好機であった。

\section{(2)「中銀カプセルタワービル」(1972 年竣エ)}

計 140 のカプセルを 2 つコアシャフトに取り付けた「中銀カプ セル」は、大阪万博を訪れたディベロッパーのオーナーが黒川に依 頼して実現した単身者用のセカンド・八ウスである注9)。当初の構想 ではカプセルは 25 年に 1 度取り替えられるはずであった。カプセ ル 1 ユニットの大きさはトレーラーで運搬可能な 10 平米 $(2.5$ メー トル x 4 メートル) とし、取り外して海や山へ移動させるという「ホ モ・モーベンス」の構想が下敷きになっている。内部は単身者が暮 らすために必要なユニットバスやベッドを有し、机や冷蔵庫などは ビルトイン方式で壁に収納されている。ただし黒川は内部空間にも こだわりを持ち、終電を逃したサラリーマンが寝るための単なる質 素な最小限空間では終わらせなかった。高価なオーディオセットな どを装備し、一人時間を楽しむための趣味の空間というコンセプト を提示した。閉ざされたカプセルの中で音楽鑑賞したり、ベッドに 横たわりながらリラックスしたり、仕事に没頭したり、誰にも邪魔 されない「個人の自由」が尊重された。

\section{(3)「カプセルK」(1973 年竣エ)}

日常から離れた場所で情報を遮断し、自由時間を楽しむのが別荘 である。黒川は家族や友人とともに過ごすための別荘「カプセル K」 を中銀カプセルとほぼ同時期に軽井沢に設計した。カプセル宣言第 4 条の「個人を中心とする新しい家庭像の確立」を示寸ための実験 住宅の位置付けである。カプセルを 4 つ用い、2つを寝室、1つを キッチン、もう 1 つを茶室としてコア部分に取り付けた。それと同 時に第 2 条の「ホモ・モーベンス」を提示することが黒川には必要 であった。宣言では「カプセルは建築の土地からの解放であり、動 く建築の時代の到来を告げるものである」と説いていたからである。 『新建築』1972 年 6 月号では、LC-30X「試作レジャーカプセル」、 MC-18X「試作ムービングコア」などいずれも移動を前提にしたカプ セルを紹介しているが実現に至っていない。実際に建設した自身の 別荘「カプセル K」では中銀カプセルと同規格の BC-25 カプセルを 用い、まるで銀座から軽井沢に移動してきたかのようにみせている。 疑似的に彼の理想のライフスタイル、つまりカプセルとともに移動 する暮らし「ホモ・モーベンス」を提示していたのだ。

\section{6. 見立てのカプセル茶室}

次に黒川が「カプセル K」でカプセルの 1 つを茶室としたことに 注目したい。実験住宅としてカプセルの 1 つに遊び心を持たせたか ったことは理解できる。非日常を楽しみ、かつ「個」を重視する趣 味の空間。黒川は音楽や映画など多くの趣味を持っていた。しかし なぜ茶室なのだろうか。「カプセル茶室」を作った経緯を探るために、 黒川の生い立ちを遡ることにする。

黒川の茶道の趣味は数寄者だった祖父の影響が大きい。祖父の実 家の愛知県蟹江市に中学・高校の 6 年間疎開していた黒川は、茶室 を勉強部屋として充てがわれた。それは「容膝庵」と名付けられた 1 畳台目の茶室だった ${ }^{i 10)}$ 。祖父の実家にはそのほか「無心庵」とい う松尾宗吾が設計した茶室もあり、そこではよく茶会が催されてい たという注11)。黒川は多感な時期、1 畳台目という最小限の空間で一 人の時間を過ごしたのである。その経験はその後の彼の空間感覚の 根幹となり、単身者用のカプセルを生み出すこととなった。「茶室と 
いう空間のスケール感、ディテールはかなり身体や記憶に焼き付い

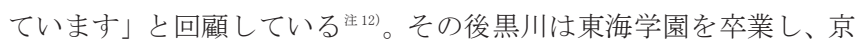
都大学に進学する。桂離宮ほか伝統的な数寄屋建築に足を運ぶが、 彼の心に残ったのは古田織部や小堀遠州らの茶室だった。千利休の 虚飾を排した無の美を追求する「わびさび」に対し、弟子の古田織 部や小堀遠州はあえて空を多く設け光を取り入れ、腰張りに暦を用 いるなど装飾性や遊びを持たせている。黒川はそれらをのちに「花 数寄」と命名し、「花数寄の花とは、異質な要素が組み込まれること によって創造される両義性の美、多義性の美」注13) と述べている。た しかに初めて黒川が手がけた「カプセル茶室」は今までにない発想 で異質な組み合わせだった。カプセルの丸空は外観からみると宇宙 船のごとく未来を象徵するデザインである。しかし内部に入ると小 堀遠州の茶室を写しており、円空は伝統的な茶室にもみられるもの で、カプセル内部にいることを忘れさせる。

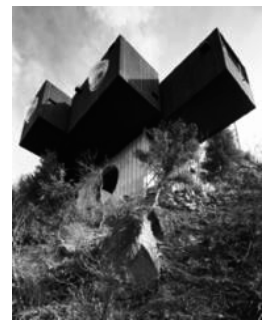

Photo1 Capsule K

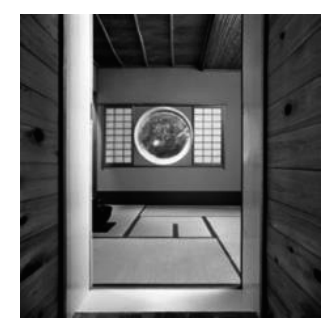

Photo2 Capsule Tea Room

\section{7. 数寄屋建築への関心}

黒川は 1976 年の「大阪ソニータワー」を最後にカプセル建築から 遠のいていく (Table1)。それと入れ替わるかのように数寄屋建築、 特に茶室へ関心を向け、Table 2 で示すように、1979 年の「栗明庵」 を筆頭に、1984 年には自邸の茶室「唯識庵」を、そしてタイのタマ サート大学日本研究所をはじめ、ベルリン日独センター、パリのパ シフィックセンターなど諸外国においても茶室を手がけるようにな る。掲載雑誌や作品集等注14-19)で調心゙てみると、それらのほとんどは 小堀遠州や古田織部らの茶室の写しであることがわかった。その理 由を探るため黒川が初めて手がけた数寄屋建築「杏樹荘・栗明庵」 と自身のマンションに設けた茶室「唯識庵」の言説をみていこう。

\section{（1）「利休ねずみ」から「花数寄」へ}

言葉を巧みに操る黒川は「利休䄈ずみ考」と題した論文を『新建 築』1977 年 9 月号に掲載し、同年に『グレーの文化』という書籍に まとめている。「利休祆ず夕」㳯20)とは「日本の空間、あるいは日本 の文化のもつ両義性、多義性を表現する象徴的な言葉として（自分 が）名付けたもの」と述べている。論文には「南方録」注21 にある利 休の茶室についての記述があり、次のように分析している。「終にか ね（寸法）をはなれ、わざを忘れることによって成立する利休の茶 室が終局的には、4 畳台目をはるかに超えてより極限的な 1 畳台目 を追求することになるのも、物理的な空間の尺度の狭さを超克して、 そこに、非日常で、非感覚的な精神空間を実現しようとするものな のだろう」。この頃の黒川は「利休齐ず夕」という言葉に表出してい るように、千利休を意識していることがわかる。利休の「極限的な 1 畳台目」と自分が青少年期に過ごした空間を重ね、そこに「物理 的な空間の尺度を超克する精神性」を捉えている。

その後、黒川は自らの手で初めて数寄屋建築に取り組む。1979 年 に「杏樹荘・栗明庵」と名付けた病院の厚生施設である。「花数寄」 という新しい造語が登場するのもそのタイミングである。

黒川の言説を読み解いていくと、自身が数寄屋建築を手がけるよ うになって初めて自身が目指すところが利休の「待庵」のような衣 装を排除した侘びの美意識ではないことに気づく。「侘び」の解釈に 疑問を持ち、千利休の弟子たちの試みに関心を移している注22!。そし て「花数寄」という言葉を用い、彼の解釈を次のように述べた。「利 休の茶の湯、茶室は、あきらかにそれまでの書院を主体とし、唐物 名物を中心と寸る茶の湯からすれば、閑寂であり、簡素であり、求 道的であり、抑制的であった。しかし、むしろ花のみあって花を感 ずることのできなかった書院茶の湯に対立する異質な草庵の精神を 持ち込むことによって、より一層花を表現したかったといえないか。 花畑に立って花を見るより、夕暮れの道端に咲く一輪の花に心を打 たれる気分といってよいかもしれない。私が侘び数寄に対して花数 寄という言葉を選んだのはこのような意味においてである」洋23)。黒 川は千利休の高弟子の古田織部や小堀遠州らの茶室に「花」を見出 し、「私は、燕庵に見られる織部の茶室を利休の茶室より花のあるも のと考えたい。(中略) 別のいいかたでいえば、伝統の形式にとらわ れない自由な創造性がある。(中略) 花数寄は、織部によって一歩進

Table2 Tea Rooms by Kisho Kurokawa

\begin{tabular}{|c|c|c|c|}
\hline 建物名・茶室名 & 竣工年 & 所在地 & 備考（参照、引用した茶室など） \\
\hline カプセル K「カプセル茶室」 & 1973 & 長野県軽井沢市 & 小堀遠州の茶室＼cjkstart注 14) \\
\hline 杏樹荘／茶室「栗明庵」 & 1979 & 東京都八王子市 & 千利休の大阪屋敷の 3 畳台目、小堀遠州の「転合庵」注 15) \\
\hline 自邸マンション「唯識庵」 & 1984 & 東京都港区 & 松花堂昭乗の滝本坊茶室「閑雲軒」（小堀遠州の「松翠亭」） 梁 16) \\
\hline タマサート大学日本研究所 茶室 & 1985 & タイ・バトンタニ & \\
\hline サルナート吉運堂 茶室 & 1986 & 新潟県白根市 & 小堀遠州の大徳寺孤蓬庵「忘鉒」 注 17) \\
\hline 朝霞荘 & 1987 & 東京都新宿区 & 企業の迎賓館 \\
\hline ベルリン日独センター 茶室 & 1988 & ベルリン & \\
\hline ジョー・プライス邸 茶室 & 1989 & ロサンジェルス & \\
\hline 道後館「儒安堂」 & 1990 & 愛媛県松山市 & 古田織部の薮内家「燕庵」注 18) \\
\hline パシフィックセンター 茶室 & 1991 & パリ & \\
\hline $\mathrm{A}$ 邸「瞽中・方寸」 & 1995 頃 & 神奈川県湯河原 & \\
\hline $\mathrm{O}$ 邸「瀑看席」 & 2000 & 東京都世田谷区 & 小堀遠州の大徳寺孤蓬庵「忘鉒」、村野紹鴎の大徳寺高林庵茶室注 19$)$ \\
\hline
\end{tabular}


められたといってよい」洋 24) と続けている。初めて手がけた数寄屋 建築「杏樹荘・栗明庵」では古田織部の「燕庵」を参照している。 例えばPhoto4をみると明らかであるが、茶室内部に空を多く設け、 明るい空間を演出している。黒川は利休の究極的な狭小空間よりも 利休の高弟子たちの試みに共感し、異質なものを組み合わせ、数寄 屋建築の自由な創造性を自身の数寄屋建築に取り入れたのだ。なお 茶室「栗明庵」は 1996 年に病院敷地内に老人施設を建設する際解 体されるが、その後八王子の老舗料亭に移築されている ${ }^{25}$ ) 。解体」 「移動」というメタボリズムの展開が数寄屋建築では可能であり、 ここで実証されている。

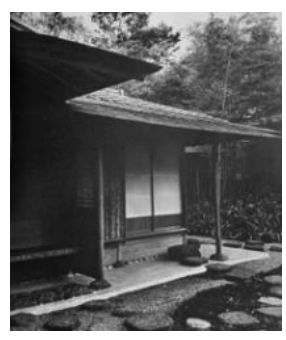

Photo3 Ritsumeian

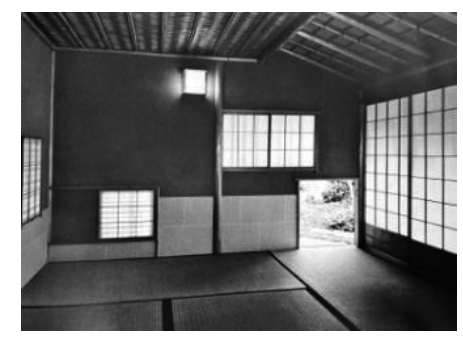

Photo4 Ritsumeian

ところで「花数寄」という造語の初出は、1980 年 5 月号の『新建 築』の論文「数寄屋考一花数寄のこと」であった。「杏樹荘・栗明庵」 の建築紹介とともに論文のタイトルとなって登場している。論文に よれば「花数寄」のきっかけは愛媛県大洲市にある「臥龍山荘」注26) との出会いと述べられている。1907 年に京都の茶室建築家・八木甚 兵衛によって設計された、不老院、臥龍院、知止庵、臥龍蓬莱山、 庭園で構成されている山荘である。臥龍院は茅莫き屋根の外観で一 見すると草庵に見えるが、それに加え民家の要素もあり、黒川が今 まで見たことのない力強いインパクトを与えた数寄屋建築だった。

「利休䄈ずみ考」で述べているバロック的な要素もあり、内部の詳 細が驚きをもって書かれており、文章からその興奮ぶりが伝わって くる。「欄間の楕円形の納まりといい、そのおおらかさは利休の草庵 の侘びを超えて、もう一つの数寄屋の傑作といってよいのではない かと思う。侘数寄に対して花数寄と呼んでもいいような精神が溢れ ている」と述べられ、ここで初めて「花数寄」という言葉が登場す る。その後黒川は「朝霞荘」（1987 年）、「道後館」（1989 年）と本 格的な数寄屋建築を手がけ、1991年にそれらをまとめた著書『花数 寄』(彰国社) を出版している。その冒頭には彼に強いインパクトを 与えた「卧龍山荘」を紹介し、「花数寄」とは「侘数寄に対抗して黒 川が名付けた数寄屋建築の様式」と明言している。異質な要素が組 み込まれることによって創造される両義性の美、多義性の美が花数 寄の「花」であり、花数寄の美意識は共生の美意識、つまり「自然 と建築との共生、部分と全体の共生、伝統と現代の共生といったも のに置き換えてもよい」注27)と述べている。

\section{（2）思索の場：「唯識庵」の実現}

1980 年代になると黒川は公共建築にも携わるようになり、1981 年福岡県庁舎、1982 年埼玉県立近代美術館、1983 年国立文楽劇場、 1985 年つくば万博（電力館、東芝館、日本 IBM 館など）、1988 年 名古屋市美術館などを手がけ、建築家としてのメインストリームを 着実に歩み始めている。茶室の設計も数は少ないながらもコンスタ
ントに手がけている。

次に 1984 年自邸マンションに設けた茶室を見てみよう。「唯識庵」 と名付けられたこの茶室は、女優若尾文子と再婚後に暮らすために 引っ越したマンション屋上のテラス部に日本庭園とともに設けたも のである。茶室の命名は中学・高校の 6 年間、東海学園で学んだ「と もいきの教え」のルーツであるインド仏教の「唯識思想」が元にな っている住28)。趣味である茶道を嘹む場として作られたが、黒川は次 第にそれ以外の機能や役割を求めるようになった。「記号論と唯識思 想の接点を探る作業に夢中になっていることもあって、唯識庵はそ の思索の場であった」洋29) と述べている。夫婦団らんのひとときから 離れ、情報を遮断し、一人で茶室空間に篭り、思索に耽けっていた ことが伺える。それは多感な少年時代に祖父の茶室「容膝庵」で過 ごした経験からきているといえる。茶室は本来の機能に加え、日常 的な思索の場へと転換していったのだ。つまりカプセル宣言と照ら し合わせてみると、第 4 条「個の確立」、第 6 条「情報の拒絶」の機 能を茶室に担わせているといえる。

「唯識庵」がつくられた頃、黒川は「共生の思想」を世に広めよ うと腐心していた。「共生」という言葉もやはり黒川がっくった概念 で、仏教の「ともいき」と生物学の「共棲」を重ねている注30)。1980 年代は建築家としての大進撃もさることながら、思想家としての活 動も活発化していく。茶室「唯識庵」で思索した共生の概念は、1987 年『共生の思想』(徳間書店)、1991 年『共生の思想 増補改定版』 (徳間書店)、1996 年『新・共生の思想』(徳間書店)の出版という 形で示された。

\section{（3）小堀遠州の写し}

「唯識庵」は石清水八幡宮にあった松花堂昭乗の瀧本坊の茶室「閑 雲軒」の起こし絵図を元に復元している。さらにさかのぼると「閑 雲軒」は焼失した小堀遠州の伏見屋敷の茶室「松翠亭」を模したも のだった。黒川は「この茶室の再現までに十七年の歳月を費やして いる」注31) と述べている。引き算すると 1967 年、つまり「カプセル K」の内部に「カプセル茶室」を作った時からという計算になる。

「カプセル茶室」もまた小堀遠州の茶室を模しており、その頃から いつしか「閑雲軒」を再現したいという願望を持っていたことにな る。なぜ実現までに 17 年もの年月が必要だったのだろうか。

黒川は堀口捨己監修による『茶室起こし絵図 第 4 集』(墨水書房) や『伏見屋敷四畳大目茶室図』をじっくり読み解き、使われている 材料や寸法を明らかにしようとした。しかしそれには限界があった ため、そこでの茶会記録である松屋久好の『松屋会記』で研究を深 めた。「寸分違わない材料を手に入れるため、年月を費やした」 ${ }^{\text {i }}{ }^{32)}$ と述べているが、なぜここまでしてこの茶室にこだわったのだろう。 その答えを探るために彼の言説を読み解いていくと、「私が命名した 『花数寄』の美意識のシンボルとして復元したかった」注33) と述べて いる。彼は自分自身の建築概念を示す「言葉」と、それを形で表す 「デザイン」を一致させるため手と頭を動かし、建築の実現と言葉 の普及に注力していた。「カプセル宣言」で前例があるように、実作 よりも先に「言葉」先行するのは彼の常套手段であった。

2002 年に放送された NHK の番組洋 34$)$ で「なぜ自宅に茶室を復元 しょうとしたのか」という質問に対し、「世界にない日本建築の原点 とは何かを考えた時に、茶室は世界のどこにもない日本オリジナル 
のもので日本建築のルーツである。自分の生活の近いところに置き、 建築活動の拠点にしたかった」と述べている。黒川にとって茶室は もはや趣味の領域を超え、日本文化のインスピレーションを与える 源として、彼の建築活動になくてはならないものとなっていたのだ。

次に茶室「唯識庵」の内部の特徵であるが、遠州が好んだ長四冨 台目という平面構成を引用している。点前座が中央にあって、長四 盢が一列に配置されているものだ。これによって舞台と客席が明確 に区切られた構成になる(Fig.1)。特に点前座に空が集中しており、 舞台性が強調されるのが写真(Photo5)でみてとれるだろう。空は合 計 12 あり、明るく華やかさを持つことで「花数寄」の意味合いを強 めている。黒川はかつての祖父のように客人を招き、本人はもとよ り夫人の若尾文子が亭主となり点前をすることもあった。その立ち 振る舞いの演出を見せるためにこのような空間構成としたのだ洋 ${ }^{35)}$

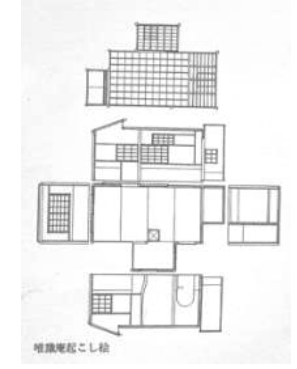

Fig.1 Yuishikian Okoshie

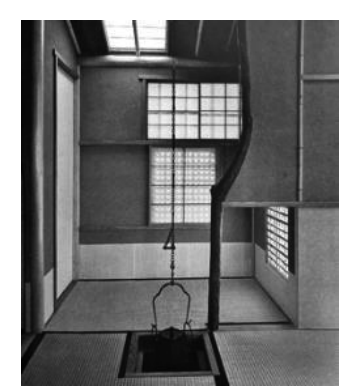

Photo5 Yuishikian

\section{8. 言葉、キーワードの重要性}

黒川にとって自身の建築哲学や思想を言い表す「言葉」は、建築 作品と同等に重要であった。Table3 はそれぞれの茶室が竣工した際、 建築雑誌に発表した論文等の一覧である ${ }^{* 36)}$ 「花数寄」という言葉 は 1980 年に初めて手がけた数寄屋建築「杏樹荘・栗明庵」の発表 時に初出し、「唯識庵」「朝霞荘」と数寄屋建築を手がけるたびに用 いている。新たな数寄屋の解釈を「花数寄」という言葉を用いて普 及させようと試みているのだ。最終的にこれら論文をまとめた書籍 『花数寄』を 1991 年に彰国社から出版している。

注目す心゙きは雑誌『建築』(1974 年 2 月号) である。「経腔胞膚 相」と題して 5 つのカテゴリーに分け、黒川紀章建築都市設計事務 所の設立以降のプロジェクト 34 件を紹介する特集が組まれている。 1960 年「K 邸計画案」など実現していない提案も含め、1962 年の 処女作「西陣労働センター」ほか、1964 年「丸亀国民宿舎ほんじま」、 1967 年「寒河江市庁舎」など白黒写真で計 42 ページに渡って紹介 されている。例えば「森泉郷カプセル K」は「胞」に属し、所員の 阿部暢夫の論文「遮断の方法論」とともに紹介されている。この特 集号のために黒川事務所内には編集委員会が設けられ、5人の所員 がそれぞれを担当している。黒川自身は冒頭に「旅のノート」、をと がきに「念」を執筆している。あとがき「念」によれば「経腔胞膚 相」の 5 文字は「従来、いろいろな言葉で表現してきた概念のキー ワードを最も近い漢字で表現するとどうなるかというゲームの中か ら選ばれたもの」と記されている。1960 年代は「メタボリズム」「ホ モ・モーベンス」などカタカナで概念を表現することが多かったが、 この頃から漢字での表現に変化していることがわかる。「念」を読み 進めていくと、最後の文章に筆者は目を見張った。「これらの混沌と
した言葉の刺激が、この 15 年間私にものを創らせるきっかけとな った。(略) イメージをコミュニケートするメディアとしてのキーワ ードになり得るにちがいない」やはり黒川にとって「言葉」は特別 なものであることがわかる。「言葉」は彼のものづくりの原動力とな り、さらに人々に想像力を膨らませ、イメージを植え付けさせるメ ディアとなるのだ。そして最後にこの一文で締めくくっている。「日 本の空間の伝統が実体そのものの伝承というよりは、概念の原型の 伝承であったように、日常の設計作業の中から一つでも多くの「言 葉」をこれからも発見していきたい」。つまり実存しているものより も概念として後世まで受け継がれるものとして「言葉」の重要性を 説いている。「言葉の発見」は彼にとって創造の源となっていたのだ。 この文章は 1974 年のものであるが、彼の姿勢はその後も変わらず 貫かれた。建築家として、思想家として、彼は「言葉」を「概念の 伝承」のツールとして最重要視していたことを裏付ける一文である。

Table3 List of Articles

\begin{tabular}{|l|l|l|l|}
\hline \multicolumn{1}{|c|}{ 建築名 } & \multicolumn{1}{|c|}{ 論文タイトルなど } & \multicolumn{1}{c|}{ 雑誌名 } & \multicolumn{1}{c|}{ 年月 } \\
\hline カプセル K ほか & 経腔胞膚相/念 ほか & 建築 & 197402 \\
\hline 杏樹荘・栗明庵 & 数寄屋考 花数寄のこと & 新建築 & 198005 \\
\hline 杏樹荘・栗明庵 & 杏樹荘・栗明庵 & 建築文化 & 198005 \\
\hline 唯識庵 & 唯識庵 & 建築文化 & 198501 \\
\hline 唯識庵 & 花数寄の系譜 & 住宅特集 & 1985 冬 \\
\hline タマサート大学 & 建築紹介 & 新建築 & 198509 \\
\hline サルナート吉運堂 & 建築紹介 & 新建築 & 198602 \\
\hline 朝霞荘 & 花数寄 & 新建築 & 198804 \\
\hline 瀑看席 0 邸 & 建築紹介 & 新建築 & 200012 \\
\hline
\end{tabular}

\section{9. 現代茶室への移行：「壼中」と「螢篭」}

最後の茶室となった「瀑看席」（2000 年）は日本画家千住博と のコラボレーションである。コンクリートの箱の 4 面に彼の滝の絵 を設置し、その内側に回廊を巡らせ、さらにその内側に四畳半の茶 室を設けている。完成までのプロセスが千住博との 1 年に渡る往復 書簡で綴られ、淡交社の雑誌『なごみ』で 1997 年 1 月から連載さ れた。そのやりとりで生じたスケッチを見てみよう。Fig.2 を見る とコンクリートの内側に茶室を設け、「非日常の世界＝壼中」と記 している。「壷中」とは中国の故事で小さな世界に大きな宇宙を感 じることをいう。黒川は「瀑看席」以前に、湯河原に「嗀中・方 丈」（1995 年頃）という名の茶室を設計しており、それ以降「壼 中」という言葉を用いるようになっている注37)。例えば「㪍中」が 登場するのは、2002 年の NHK のドキュメンタリー番組「美と出 会う 黒川紀章 全身これ建築家」でのインタビューである。自邸 の茶室「唯識庵」で撮影されたシーンの背後に「壼中」の掛け軸注 38)がかけられている。意図的に床の間に飾り、視聴者の目に映るよ うに演出しているのだ。その翌年 2003 年に発売された DVD「北 欧建築と日本のフォルム」のタイトルも「壼中」と名付けている。 これは監督イェスパー・ワクトマイスターによるドキュメンタリー 映像で、建築家らが自作について語るものだ。DVDの冒頭は「瀑 看席」が登場し、その後アルヴァ・アアルトの「マイレア邸」、安 藤忠雄の「本福寺水御堂」等が続く。黒川は「瀑看席」のほか、 
「カプセルハウス K」、「中銀カプセル」、「ソニータワー大阪」 を紹介している。黒川は「壼中、それは小さな空間で無限の宇宙を 感じること」とその概念を「カプセル茶室」で語る。「壼中」の概 念は「瀑看席」の構想段階からあったにも関わらず、それを語るの は「カプセル茶室」の内部であることに筆者は注目する。つまり彼 の原点である「カプセル茶室」にも設計当時は意識していなかった が「壼中」の概念が含まれているということを示唆しているのだ。

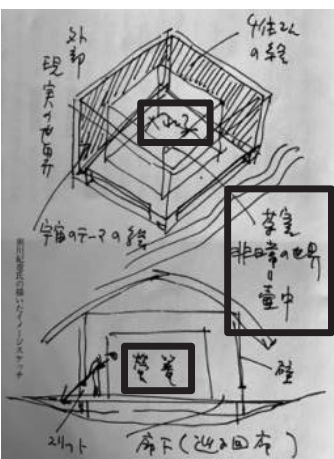

Fig.2 Sketch Takimino-seki

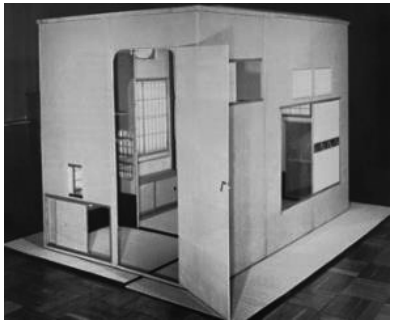

Photo6 Rokkaen

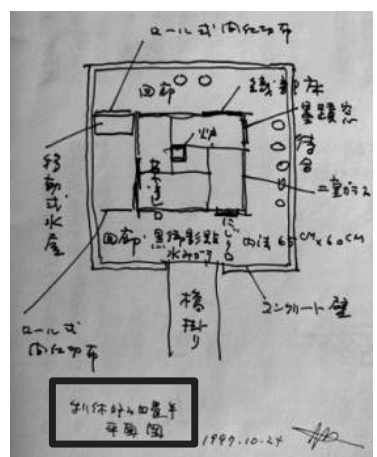

Fig.3 Sketch Takiminoseki

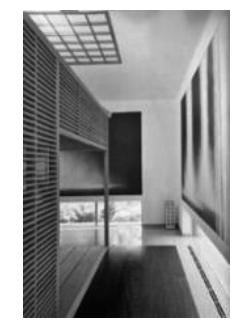

Photo7 Takiminoseki
もう一度スケッチ Fig.2 を見ると、その上下に「入れ子」「螢 篭」と書かれている。「螢篭」とは西本願寺所蔵の組立式移動式茶 室のことである。黒川は 1981 年にロンドンのロイヤル・アカデミ ー・オブ・アーツで開催された「江戸大美術展」の会場構成を行な いこの時に組立式茶室「Rokkaen」(Photo.6) と出会っている。 展覧会カタログによれば「螢篭と同じ製造者によって、同じ頃 1790 年代に作られたもので、折りたたむと $38 \times 189 \times 88 \mathrm{~cm}$ になる」 注 39) と記されている。屏風仕立てで簡単に運搬できる組立式茶室 は、まさに黒川が推奨していた「ホモ・モーベンス」の考え方の実 例であった。海を渡り、ロンドンで展示された組立式茶室は黒川の 会場構成によって展示室の中央に配置された。黒川はこのイメージ をずっと温めていたのだろう。0 邸茶室のプランニングの早い段階 で「螢篭」のイメージを千住への往復書簡で伝えている。「千住さ んの四面の宇宙の絵に囲まれた「螢篭」の中にもう一つの宇宙が

「入れ子」になるという 3 重の次元の逆転は、この茶室を世界の注 目の下に置くことになるかもしれません」注 40) とこの構想を推し進 めている。さらに黒川は茶室内部からの景観を考慮し、小堀遠州の 大徳寺孤篷庵茶室「忘鉒」の雪見障子を引用した。これは他の茶室 でも用いている手法である。コンクリートの箱の内側四面に千住の 春夏秋冬の滝の絵が展示され、その下のガラスの開口部からは自然 光が入り込み、外部との接点となる。これは「自然との共生」を意 図したものである。平面構成に関してはスケッチの Fig. 3 に「利休
好みの四畳半」と書かれているが、黒川は当初から正方形にこだわ っていた。最終的に行き着いたのが道庫も床もない千利休以前の武 野紹鴎が提案し、利休も好んだ「床無四畳半」の平面だった注41) な お黒川がスケッチに日付とサインを入れるようになるのは 1997 年 頃である。そのきっかけは 1997 年 6 月にパリのポンピドーセンタ 一で開催された「黒川紀章メタボリズム1960-1975」展だった。展 覽会ではスケッチが展示され、その後スケッチ 45 点がパーマネン トコレクションとして買い取られた。それを機にオリジナルスケッ チのアーカイブ化を意識し始めるようになったのだ注 ${ }^{42}$ 。

\section{考察・まとめ}

年代順に黒川のカプセル建築および茶室に関して、彼の言説やキ ーワードと関連付けて論じてきた。ここで以下の 4 点から整理し直 し、黒川の設計活動や思想活動についてまとめる。一つ目は「造語 表現と建築表現」である。自らを思想家と名乗る黒川にとって、言 葉を造ることも建築を設計することも表現者として同等の価值を有 していた。二つ目は「青少年期に形成されたもの」である。中学・ 高校の 6 年間、東海学園に通っていた黒川は仏教の教えを習得し、 疎開先では茶室を勉強部屋としていた。三つ目は「現代に受け継ぐ 日本の伝統」、四つ目は「ミニマムな空間に求めた世界観」であ る。本研究の結論として以下に詳述する。

\section{(1) 言語表現と建築表現}

メタボリズム・グループの一員だった黒川は「カプセル」の有用 性に着目し、1969 年に「カプセル宣言」を打ち出す。そこでカプ セルの可能性を 8 つ条文で示し、第 1 条は「サイボーグ」、第 2 条では「ホモ・モーベンス」等の言葉を用いて人々の気を惹いてい る。彼にとって「新しい建築の概念」は「新しい造語」によって語 られるものであり、建築を構想することも、新しい言葉を造ること も、彼の表現活動には等価であった。彼にとっての建築は造形表現 に留まらず、その根底にある思想表現でもあったといってよい。思 想や美意識が詰まって完成した建築を建築雑誌等で発表する際、気 を惹くような「新しい造語」が必要であった。松葉一清は「惹句の 名手」と揶揄したが、キーワードで新しい建築概念を示していく手 法は黒川独自のものといえる。そして松葉が言うように黒川は「コ トバ」の人であるため、彼の作品や思考を理解する上で大きな手が かりとなった。その推移を見ていくと、当初は「サイボーグ」「カ プセル」などカタカナを用いて近未来なアイディアを表していた が、その後は漢字を組み合わせた日本的な表現へと変化していく。

「利休ねずみ」「花数寄」などはいずれも日本文化、特に茶道文化 から発想された表現であり、数寄屋建築への関心の移行と時期が重 なる。また「共生」など仏教思想からも着想を得て造語が生まれて いる。

このような新しい概念と造語は建築作品と対になって建築雑誌で 発表され、造語は論文のタイトルとなった。もちろん造語の命名者 は自分であることを主張するのを忘れない。「言葉」が先行し、デ ザインが「言葉」を実証するものとして後から作られるのも彼の常 套手段であった。そして自分の造語を一般化させようと、次の戦略 として書籍化に注力している。その際、名だたる建築評論家や建築 史家の評論が添えられた。書籍は英語だけでなく中国語など多言語 
に翻訳され、訳された造語とともに彼の思想や建築作品は世界中に 広まっていった。書籍数は他の建築家に比べ圧倒的に多い。また若 い頃からカリスマ性のあった黒川は、説得力のある独特の語り口で 講演会にのぞみ、観客の心を熟掴みにした。自らの建築思想や建築 作品を広めるため、「話し言葉」や「書き言葉」を巧みに操る稀有 な存在の表現者であった。

\section{(2) 青少年期に形成されたもの}

黒川は「自分の誕生日は釈迦と同じく 4 月 8 日である」と筆者ほ か所員の前で自慢げに語ったことがある。黒川は中学・高校時代に 通った仏教系スクール東海学園で「ともいきの教え」に共感し、思 想家として仏教思想を下敷きに独自の理論を展開している。そして 自邸の茶室を「唯識庵」と名付け、そこで記号論や唯識論と対峙 し、「共生」という新たな造語を生み出した。いずれも東海学園で の仏教の学びから展開させていったものだ。

次に彼の人生に多大な影響を与えたものとして、祖父の影響を指 摘する。戦時中、名古屋から疎開した祖父の家には茶室があり、祖 父の周りにはいつも文化人が出入りしていた。黒川の父は建築家で あったが、文化・芸術の素養は数寄者だった祖父のもとで身につけ たといえる。自邸の茶室「唯識庵」の完成まで 17 年もの年月を要 したのも、数寄者の祖父の血筋を受け継ぎ、本物への執着からであ った。

その祖父の茶室で多感な青少年期を過ごした経験は「単身者向け のカプセルマンション」の発想の規範となった。黒川はたった 1 畳 台目の茶室で 6 年間過ごし、極限までに削ぎ落とされたミニマムな 空間における合理性などを多感な時期に体得した。そしてスケール 感だけでなく、空間の持つ精神性も感受性豊かな黒川は享受した。 自邸の茶室「唯識庵」を「独りで思索する場」とみなしていたのは 青少年期に過ごしたこの経験が下敷きになっている。

\section{(3) 現代に受け継ぐ日本の伝統}

1960 年代後半からメタボリズム・グループに属し、最少年メン バーであった黒川は「カプセル」に未来の可能性を見出していた。 プレファブリケーションに関してはソ連で実例を見聞し、初めての 著書『プレファブ住宅』でその有効性を示している。黒川がカプセ ルに求めた工業化、寸なわち材料のプレハブ化・量産化は、茶室に 対する取り組みとは真逆である。茶室はある意味芸術品ともいえ、 建て主のこだわりや美意識が反映される。こだわりを実現するため に数寄屋大工の優れた技術や材料の希少性などを要する。だが接点 があるとすれば、中銀カプセルにおいては当時最も高価だといわれ た電子計算機やソニーのテレビ、オープンリールのカセットなど憧 れの電化製品を備え付けている点である。これを茶室に置き換える と床柱、床框などのこだわりの素材の扱いとみていいだろう。

25 年に 1 度カプセルを取り替えることを想定していた「中銀力 プセル」は、20 年に 1 度行われる伊勢神宮の遷宮がアイディアの 源といえる。黒川は毎年のように伊勢神宮を訪れ、伊勢神宮こそ

「発見の原点」であり「日本文化の根源」と述べている。「伊勢神 宮は千二百年の歴史を持つといいますが、実は二十年ごとの遷宮と して、二つの敷地を交互に使って建て替えられています。いいかえ れば素材（物理的）そのものは、二十年ごとに新しくなっているわ
けで、これを西欧の概念ではオリジナリティではなく、コピーとい うことになります。しかし日本人は伊勢神宮をコピーとは考えませ ん。このことを私は日本人のもつ見えない伝統と呼んでいます」注 13)。つまり受け継がれていくこと自体に重きを置いているのであ る。黒川はカプセルの交換によって更新していく着想を日本の伝統 建築から得ていた。

このように黒川のアイディアの源は常に日本の伝統文化への敬い から生じている。実際に自らが茶室を設計する段になると、歷史的 茶室の写しという形でこの世に再び蘇らせている。例えば小堀遠州 の「松翠亭」は焼失後「閑雲軒」として復元されるが、さらに黒川 によって「唯識庵」として現代に蘇っている。また黒川の初めての 数寄屋建築「栗明庵」は施主の意向で解体されることになったが、 他者に譲られ場所を移して再建されている。茶室を解体して移築す ることは珍しくないが、黒川は偶然にも海外で日本の組立式茶室と 出会い、茶室の広範な可能性に開眼寸る。組立式茶室はカプセルで 叶わなかった「ホモ・モーベンス」を体現していたからだ。それが のちに実現する現代茶室「瀑看席」への布石となった。その際黒川 は「カプセル」ではなく「コンクリートの箱」の中に「螢篭」の入 れ子として組み込み、現代美術とのコラボレーションによって新し い形の現代茶室を生み出した。

\section{(4) ミニマムな空間に求めた世界観}

「カプセル」と「茶室」。そのミニマムな空間に彼が求めて行き 着いた世界観は何か。それは「壼中」という言葉で言い表されてい る。中国の故事に由来する「䨐中」は四方を壁に囲まれた小さな空 間のなかで壮大な思想が現出し、無限の宇宙を感じることをいう。 黒川は多感な時期に「容膝庵」という 1 畳台目の空間でその胸中を 知る。「利休初ずみ考」で述べたように当初は「物理的な空間の尺 度を超克する精神性」と表現していた。その空間体験の再現をカプ セルという工業化製品で試みるがカプセル建築が普及することはな かった。その後伝統的な数寄屋建築を手がけるようになり、最終的 に現代茶室「瀑看席」でコンクリートの中に「壷中」の空間を作り 出した。禅語「壶中日月長」からとった「监の中の小さな世界」で ある。DVD「嗀中」でその言葉の概念が語られるのは、黒川が最 初に手がけた「カプセル茶室」であった。つまり小さな空間で壮大 な宇宙を感じる「壶中」の世界観は「カプセル」でも存在していた ことを意図した演出である。その世界観を示すに相応しい「壷中」 という言葉に出会うのは晚年であるが、それは彼の建築哲学として 以前からあったことを示唆している。

黒川は日本の伝統を引き継ぎながら、どう現代に表現するかを追 い求めた建築家である。本研究ではカプセルや茶室を通じ、彼の言 説を読み解いた。「言葉」を重視し、概念の伝承を重んじ、それを 説き続けた黒川の姿が浮き彫りとなった。

\section{図版出典}

Photo1,2: 大橋富雄撮影、提供

Photo3:『新建築』(1980 年 5 月号)

Photo4：『別冊新建築 黒川紀章作品集』（新建築、1986）p.87

Photo5：『別冊新建築 黒川紀章作品集』（新建築、1986）p.121

Photo6:『The Great Japan Exhibition: Art of the Edo Period 1600-1868』

(Royal Academy of Arts London, 1981) p.296

Photo7：雑誌『なごみ』（淡交社、2000 年 6 月号）p.5 
Fig.1：『建築文化』（1985 年 1 月号） p.130

Fig.2:『平成の茶室を創る 黒川紀章 千住博「往復書簡」』（淡交社なご み 1997 年 $1-12$ 月号) p.11

Fig.3: 同上『平成の茶室を創る 黒川紀章 千住博「往復書簡」』p.48 Table1,2,3 : 筆者作成

\section{注}

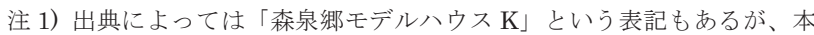
論文ではもっとも多く用いられていた「カプセル K」と表記する。

注 2）黒川紀章建築・都市設計事務所公式ホームページより

注 3)「万博という問題系 1 都市、万博、メタボリズム--破壊と再生のプロ グラム-黒川紀章インタヴュー (特集 万博の遠近法)」（INAX出版、 2004 年、No.36、pp.64-79) 。次号では「1990 年代以降の建築・都市 (13)仏教とメタボリズム--黒川紀章論」（INAX 出版、2004 年、No.37 pp.37-40）を論じている。また五十嵐は黒川の死後『建築ジャーナル』 2007 年 12 月号にて「黒川紀章が大衆に発信し続けた建築家像」という追 悼文を寄せている。

注 4）建築家のレム・コールハースとキュレーターのハンスニウルリッヒ・ オブリスト、太田佳代子らが 2005 年から生存するメタボリスト、同僚、 弟子、家族らにインタヴューを行ない、それらを写真資料とともにまとめ たドキュメンタリーブック。日本語版『プロジェクト・ジャパン メタボ リズムは語る』は 2012 年に出版。

注 5）カプセルについては 1969 年に刊行された黒川紀章著『ホモ・モーベン ス 都市と人間の未来』(中公新書) に掲載された「カプセル宣言」を読み 解いていく。茶室や数寄屋建築については黒川紀章著『花数寄』(彰国社、 1991 年）を中心に読み解いていく。黒川の思想に関しては彼の集大成 ともいえる『新・共生の思想』（徳間書店、1996 年）を読夕解いていく。筆 者は 2000 年に黒川紀章建築・都市建築事務所の社長室秘書課に入社し、主 に広報やアーカイブ担当として勤務した。入社前に黒川に手渡されたのが 『新・共生の思想』であり「僕の著書を隅から隅まで読みなさい。ここに 僕の思想が全て入っている」と言われた。

注 6) 1962 年に提案したデザインコンセプト。箱型のコンクリートユニット 数種類を量産し、その組み合わせによって、公団型の集合住宅をつくると いう実験的な工法の研究。箱型コンクリートユニットの増設による成長も 可能なメタボリズムとリサイクルの建築。

注 7）都市論をめぐるディスカッションの際、多田が人間のパターンを、寓 民・遊民・動民という三つの型にわけたらどうかと提案したことから、黒 川は「動民」という言葉に着目した。「動民」とは「みずからの欲する価 值・目的を求めて積極的に動こうとする人間」と定義している。

注 8）黒川紀章『ホモ・モーベンス』（中公新書、1969 年）p.150-151

注 9）「万博という問題系 1 都市、万博、メタボリズム--破壊と再生のプロ グラム-黒川紀章インタヴュー」『10+1 特集 : 万博の遠近法』（INAX 出版、2004 年) p.68

注 10）「江戸中期のものと思われる珍しいもの」と記されている（別冊新建 築『黒川紀章作品集』（新建築社、1986） p.215

注 11）「祖父の印象は毎日家にいて茶会を開いたり、庭の手入れをしたりし ている粋人という印象があります」（別冊新建築『黒川紀章作品集』（新 建築社、1986) p.215

注 12）別冊新建築『黒川紀章作品集』（新建築社、1986）p.215

注 13）黒川紀章『花数寄』（彰国社、1991 年） p.4

注 14） The Japan Architect 18 「黒川紀章 1988-1995」（新建築社、1995） p.228

注 15）前掲『花数寄』p.64

注 16）前掲『花数寄』p.87

注 17）前掲『黒川紀章作品集』p.108

注 18）『学芸和風建築叢書 現代茶室の試み』（学芸出版社、1993 年） p.89

注 19）『平成の茶室を創る 黒川紀章 千住博「往復書簡」』（淡交社なご み 1997 年 $1-12$ 月号) p.49

注 20）「利休ねずみ考」『芸術新潮』（1979 年 6 月号）墨染布子色を利休ねず
みと呼ばれる色彩で、江戸後期になると粋な色として流行するようになっ た。それは「矛盾するいくつかの要素を衝突させて、相殺することによっ て得られる共存的連続の状態、あるいは非感覚的状態」と定義している。 注 21）利休の弟子の南宗寺集雲庵主・南坊宗啓が口伝秘事を伝えた茶書 注 22）黑川は「茶の始祖と言われる珠光、紹鴎から千利休へと、侘茶こそ茶 の道の真髄といわれてきている以上、「わび」が日本の伝統的な美意識で あることは否定できない。しかし問題なのはその解釈である」と述べてい る。前掲『花数寄』p.4

注 23）前掲『花数寄』p.59

注 24）前掲『花数寄』p.60

注 25）「杏樹荘・栗明庵」が建設された八王子市にある永生病院の現理事長 安藤氏に筆者が行なったインタヴュー調査 (2020 年 3 月 26 日) より判明。

「杏樹荘」は現存するが「栗明庵」は平成 8 年に病院敷地内に老人施設を 増築する際、八王子市の老舗料亭へ寄贈した。移築し再建されたが、その 後解体され、現在の所在は不明である。

注 26) 2016 年に国の重要文化財となる。黒川が最初に訪れたのは 15 年前と 述べていることから 1976 年頃と推測される。前掲『花数寄』p.7 注 27）前掲『花数寄』p.7

注 28）東海学園時代に恩師の椎尾弁匡より「ともいき仏教」の教えを受け、 そのルーツであるインド仏教の「唯識思想」に関心を持った。

注 29）前掲『花数寄』p.91-92

注 30）黒川は京都大学に進学し、「大学 2 年生の頃から本格的に唯識思想の 研究に入った。（略）以来四十年近く「共生の思想」を私なりに発展させる ことに力を注ぎ込んできたのである」（前掲『新・共生の思想』p. 23）「共 生」という言葉を公に用いはじめたのは『共生の時代』(講談社、1981 年) の執筆に取り組み始めた 1979 年だと明記している。その翌年行われた「横 浜デザイン会議 1980」で初代議長を務め、テーマを「共生の時代」とし、 それ以降国内外で「共生」をテーマにした講演会を頻繁に行うようになっ た。

注 31）前掲『新・共生の思想』p.203

注 32）前掲『新・共生の思想』p.20

注 33）前掲『新・共生の思想』p.20

注 34) NHK 教育テレビドキュメンタリー「黒川紀章 美と出会う「全身これ 建築家」より (2002 年 8 月 31 日放送)

注 35）「唯識庵」『建築文化』（1985 年 1 月号）より

なお現在の茶室は所有者が変わり「喜十郎庵」と名が変わっている。(2020 年 10 月 2 日、伊藤文子インタビューより)

注 36) Table2 の一覧にまとめた「壶中・方寸」など個人所有で雑誌未発表の 茶室の存在は黒川紀章建築・都市設計事務所の社歴書から引用。筆者は元 所員の茂木愛子にインタビューを試みた。彼女はほぼ全ての茶室を担当し ているが、「黒川先生はコンセプト重視で数寄屋建築のディテールは施工者 に委衫るところが大きかった」と述べている。（2019年 8 月 8 日、黒川建 築都市設計事務所にてヒアリング)

注 37）『花数寄』（1991 年）や『新・共生の思想』（1996 年）では「壼中」 といら言葉は見当たらない。

注 38）博報堂取締役社長であった近藤道生からいただいた書であるが、近藤 は茶人でもあり、空中庭園にある唯識庵の主という意味で、黒川の雅号を 「唯識庵空中」と名付けている。『平成の茶室を創る 黒川紀章 千住博「往 復書簡」』p.12

注 39) 『The Great Japan Exhibition: Art of the Edo Period 1600-1868』

(Royal Academy of Arts London, 1981) p.296

注 40）前掲『平成の茶室を創る 黒川紀章 千住博「往復書簡」』p. 13 注 41）前掲『平成の茶室を創る 黒川紀章 千住博「往復書簡」』p. 48 注 42）筆者が黒川事務所に勤務していた 2000-2001 年はオリジナルドローイ ングにサインを入れるものとそうでないものがあった。そうでないものに 関しては、裏側にアーカイブ担当者が鉛筆書きで日付を記し、プロジェク トごとにフォルダーに収納していた。

注 43）前掲『平成の茶室を創る 黒川紀章 千住博「往復書簡」』p.16 


\title{
CONSIDERATION OF CAPSULE AND TEA ROOM DESIGNED BY KISHO KUROKAWA
}

Worldview of "Kochuu"

\author{
Nahoko WADA*1 \\ ${ }^{* 1}$ Representative Director, Access Point: Architecture-Tokyo, Ph.D.
}

"Nakagin Capsule Tower Building" established in 1972 is a world well-known architecture as a symbol of Metabolism architecture designed by Kisho Kurokawa. The architect regards capsule as living cell which have to be replaced every 25 years in order to realize the recycle system of Metabolism architecture, but never exchanged. "Nakagin Capsule Tower Building" is apartment house for single man. Total 140 capsules are attached to the core shaft. At the same time, he designed his summer cottage "Capsule K" in Karuizawa consisted by 4 capsules as an experimental house. One of them is a tea room, because tea ceremony is his hobby. However, the metabolism movement came to be ended in the late 1970's, he has continued to design tea room since he built traditional Sukiya Architecture "Kyoju-so" and tea house "Ritsumei-an" in 1979.

Kurokawa put the new word "Hana-Suki" for the concept of new Sukiya architecture. Then, he built his own tea room "Yuishiki-an" in 1984 which named from the philosophy of Buddhism. Finally, his last tea room "Takiminoseki" was completed in 2000 collaborate with Japanese painter Hiroshi Senju which is into a concrete box.

The author researched his capsule architecture, tea rooms and his texts to clarify his view of capsule and tea room and concluded the following fourpoints:

1. The expression of spoken and written words by Kisho Kurokawa are equal to the expression of architecture. He often created new words for showing his new concept of architecture and published over 100 books and had lectures. It was necessary for him to spread his new philosophy.

2. The fundamental philosophy of the architect was formed by the experience of young ages in Kanie city of Aichi prefecture during the World War II. He learned the Buddhism at junior and high school. For example, not only the name of his tea room "Yuishiki-an" but his main philosophy "Kyosei" is also inspired from Buddhism. He spent his young ages at tea room "Yoshitsu-an" in Kanie. His grandfather was "Sukisha" which is cultural person and Sukiya collector. His grandfather gave a great impact to young Kurokawa and he got the aesthetic eyes at small tea room of traditional Skiya architecture. It led to the concept of Capsule architecture to spend at the minimum space alone.

3. Japanese tradition gave him the inspiration for his new creation. Especially, tea room was regarded as the symbol of Japanese original culture. The concept of Japanese tradition was translated by Kurokawa and got reborn as contemporary architecture.

4. He prefer to use the word "Kochuu" for the minimum space in his late years around 2000. He designed "Takiminoseki" into the concrete box in 2000 which was similar to Capsule architecture. Although the material was different, the concept was the same as tea room at "Capsule K". For him, the worldview of "Kochuu" which means to feel universe at minimum space, is important to express his concept. He realized the world view of "Kochuu" was unvarying concept and has continued from the beginning of his carrier since "Capsule K" was completed in 1973. 